\title{
ASSESSMENT OF PSYCHOLOGICAL WELL-BEING, SOCIAL SUPPORT AND COPING STRATEGIES OF PATIENTS WITH AMPUTATION ATTENDING CLINIC AT NATIONAL ORTHOPAEDIC HOSPITAL, IGBOBI, LAGOS, NIGERIA
}

\author{
Emordi Mojisola Adepeju and Aina J. O.
}

\author{
School of Nursing, Babcock University, Ilisan, Ogun State
}

Cite this article:

Emordi M.A., Aina J. O. (2021), Assessment of Psychological Well-Being, Social Support and Coping Strategies of Patients with Amputation Attending Clinic at National Orthopaedic Hospital, Igbobi, Lagos, Nigeria. African Journal of Health, Nursing and Midwifery 4(3), 15-34. DOI: 10.52589/AJHNMGBOJVMVC.

\section{Manuscript History}

Received: 14 May 2021

Accepted: 27 April 2021

Published: 29 May 2021

Copyright $(92020$ The Author(s). This is an Open Access article distributed under the terms of Creative Commons AttributionNonCommercial-NoDerivatives 4.0 International (CC BY-NC-ND 4.0 ), which permits anyone to share, use, reproduce and redistribute in any medium, provided the original author and source are credited.

\begin{abstract}
Amputation affects the patient physically, psychologically, socially, economically, and spiritually. The highest number of prevalent traumatic amputations was in East Asia and South Asia followed by Western Europe, North Africa, and the Middle East, high-income North America and Eastern Europe. Similarly in Nigeria, amputation has devastating effects on individuals, and on the economy. A number of researchers have invested time and energy in reducing the challenges but it appear that the number of depression and other effects are increasing daily. Therefore, the research aimed at assessing the psychological well-being, social support and coping strategies of patients with amputation. The study adopted a quantitative descriptive cross-sectional designed to investigate the psychological well-being of amputees. Total enumeration was adopted for the research. A validated questionnaire was used with a Cronbach's alpha internal consistency ranging from 0.81 to 0.81 . Data were collected and analyzed using IBM SPSS version 23 to generate summaries of descriptive statistics and inferential statistics. Results showed that the age ranged of the participants were from 25-34 years. The characterization of the degree of Psychological well-being of patients shows that majority of the respondents are of high level of disappointment, discouragement, dissatisfaction and despondent about their present conditions and life. Similarly, the first regression result indicate that there is a significant relationship between the psychological well-being and coping strategies which affects the duration of the amputees attending the clinics with [R2 $=.721, R 2$ adj $=.558, F(27,46)=4.411, p<.001]$, therefore this hypothesis was accepted. Also, the second hypothesis indicated that there is a significantly relationship among the psychological well-being, social support and coping strategies of amputees attending clinic with $[R 2=.909, R 2$ adj $=.805, F(39,34)=8.748, p<.001]$. Therefore, this hypothesis was accepted. The study concluded that complexity of psychological well-being, social and coping strategies in the lives of human being and their inter relationships were well exposed and their relationships were evaluated. Future research should be conducted on a larger sample, using a mixed-method approach to uncover a large diversity of coping efforts used, by individuals who had a lower limb amputation.
\end{abstract}

KEYWORDS: Psychology, Coping, Stress, Depression, Lower Limb, Upper Limb. 


\section{INTRODUCTION}

\section{Background to the Study}

It is generally believed by most religions that man is created in the image and likeness of God. The physical features of a human being are those of his creator who is the prototype, a perfect physical, spiritual and psychological being. Physical deformities at birth are a deviation from the perfect feature of human beings, and this becomes a psychological distress to parents and family members. The efforts to correct deformities are usually the priority of the parents because the physical state of a human being affects the psychological well-being of that person, and will eventually influence his well-being if not effectively managed. The psychological well-being of a physically challenged person is important to their mental health; therefore, amputation - either traumatic or pathologic — is a deviation from the perfect feature of God's plan for human beings. The biological feature of maintaining balance without artificial support in the active stage of life is the ability to stand on two legs to facilitate movement. To carry out activities of daily living, using the two hands and the two legs are required for the functions of activities. When the hands and legs are incomplete, either due to congenital abnormality, traumatic amputation or other forms of pathogenic disorders, the psychological well-being of that person is affected.

According to the World Health Organization (WHO, 2011), health is a concept stressing social, personal resources and physical capacities. Health was further defined as a state of complete physical, mental and social well being, and not merely the absence of disease or infirmity. Hence, being healthy entails being in good physical, mental and social states, and is not limited to illness or disability.

Olukolade, Alao and Adebisi (2013) noted that psychological well-being is a state of complete wellness when one considers the mental status of individuals. On the other hand, Gilbert (2018) stated that psychological abnormality is a term, which describes unpleasant emotional states that have negative impacts on an individual's level of functioning. It is also conceptualized as emotions that disturb normal functioning and inhibits the individual from carrying out normal functions. Thus, the hallmark of psychological distress is troubling states that interfere with the normal functioning processes of individuals. That is a reason some scholars viewed psychological distress as a mental illness while some others see it as a symptom of mental illness (National Institute of Mental Health, 2018). In either case, there is a strong reason to conclude that a strong association exists between psychological distress and mental illness (Eyisi, 2019). Hence, any factor that negatively affects the mental health of an individual will also generate negative emotions, which will further affect the individual's psychological wellbeing. One of such many factors can be amputation.

According to Ryff (2014), psychological well-being has six components, which are autonomy, personal growth, purpose in life, acceptance of situation, environmental mastery and positive relation with others. An amputee's psychological well-being is affected mostly in selfacceptance of deformities in their image, and environmental mastery due to disability that makes them dependent on others to accomplish some activities of daily living. Positive relation with others is affected because of self image that is distorted due to an amputated arm or leg; purpose in life is affected especially when the upper limb is involved and the dominant arm is amputated, the individual feels dissatisfied and disappointed with himself or the situation. Most patients who lose a limb as a result of traumatic or surgical procedures encounter a series of 
complex psychological responses often characterized by feelings of despair and phantom pain, as mentioned by Adebayo and Ayiade (2011). Pain, in this sense, is a construct that is very difficult to describe despite its frequent usage. Borsook and Becerra (2009) stated that pain is the unpleasant sensory and emotional experience associated with actual or potential tissue damage. Thus, in an attempt to describe what pain is, Borsook and Becerra (2009) stated that with pain, there could be an actual tissue damage such as damage to one's hands or head, or a potential tissue damage. Then again, the researchers revealed that there could be an 'unpleasant sensory and emotional experience' component to the actual or a potential tissue damage. Hence, pain has an emotional component to its manifestation (Ohenewa, 2017). In addition to this, pain can be physical and some physical injuries that can result in physical pain include amputation. Also, pain can be psychological; terms associated with this include "emotional pain", "psyche-ache or psychological pain" and "mental pain" (Orbach, Mikulincer, GilboaSchechtman \& Sirota, 2003). By implication, the physical pain and associated trauma could culminate in unpleasant emotional experiences that lead to psychological consequences in amputees (Ohenewa, 2017).

The psychological state of the individual amputee is equally important in understanding the total well-being of the patient. Therefore, early recognition and treatment of psychological distress among amputees is very important in preventing long-term disabilities. Amputees' perceptions of their bodies and their psychological well-being have evoked keen interest among researchers; this is because an alteration in an individual's body image sets up a series of emotional, perceptual and psychological reactions, which can be fatal if not dealt with in time.

Amputation is a traumatic state of being that people do not bargain for. It deprives individuals of their normal human functioning capacity and makes them dependent on other people, even against their will. It is another dimension of loss that stirs up unpleasant emotional experiences, as said by Borsook and Becerra (2009), which consequently leads to emotional pain. Amputation is the removal of one or more parts of the body and can be as a result of unprecedented havoc or natural disasters such as accidents, earthquakes of major intensity, terrorism and war, or carried out due to medical reasons with the motive to improve health outcomes and quality of life (QoL) of patients (Sinha, 2013). Amputation, involving the severance of a limb or part of it is the most ancient of all surgical procedures carried out for punitive or therapeutic reasons and can be the result of trauma, malignancy, disease or congenital anomaly (Adejumo \& Adejumo, 2005; Amputation Coalition of America, 2010). Iqbal, Mohamed and Mohamad (2019), citing the World Health Organisation (WHO, 2005) observed that $0.5 \%$ of the population of a developing country suffer from disabilities following amputation that requires prosthesis or orthosis and related rehabilitation services.

According to Ohenewa (2017), some of the conditions that can lead to amputation include tumor of the bone, soft tissues, blood vessels or of the nerves; infections which refuse to respond to conservative measures and thereby contributing to sepsis; and peripheral vascular disease. In cancer patients, amputation is performed as a lifesaving procedure to protect from further malignancy of the body part or from spreading to other parts of the body. In debilitating vascular conditions of the extremities, limb gangrene, leprosy, and so on, amputation is carried out to inhibit progression or to restore functions of that body part by making it amenable for prosthesis, and thereby making the person mobile. Also, inadequate management of diabetic foot ulcers can also be a precursor of lower limb amputation. Furthermore, a series of factors could be the cause for amputation. Nellie (2010), citing Flannery and Faria (1999), stated that amputations are 15 times more likely to be needed in persons with diabetes than in persons 
without diabetes, not only because of macro-vascular changes, but also micro-vascular, autonomic, and sensory neuropathic changes. Hence, diabetes is the cause for nearly $80 \%$ of the traumatic amputations, with atherosclerosis or chronic arterial occlusive disease as the underlying pathology.

\section{Statement of the Problem}

Amputation, unlike other surgical interventions, though carried out to save lives, is irreplaceable, even the prosthesis is never the same as the natural limb. Due to the fact that limb amputation is almost a daily surgical procedure in the hospital, the psychological wellbeing of patients with amputation is given negligible attention, until some of these patients start to manifest some socially unacceptable behaviours while on admission; then, the psychologist is invited to review the patient.

Approximately 185,000 amputations are carried out every year in the U.S. as a whole with an estimated one out of every 190 persons currently living with limb loss (Ziegler-Graham, MacKenzie, Ephraim, Travison \& Brookmeyer, 2008; Laura, 2012).

Despite calls by the World Health Organisation (WHO) and the U.S. government to reduce lower limb amputation rates (U.S. Department of Health and Human Services, 2000; Laura, 2012), it has been estimated based on current trends that the number of persons living with amputation will increase over twofold to 3.6 million by the year 2050, as a result of population aging and associated increases in the number of people suffering from these vascular conditions, particularly diabetes.

Amputation affects the patient physically, psychologically, socially, economically, and spiritually; the family; if married, sexually; if unmarried, chances of having suitors; if employed, it will affect the productivity; if unemployed, being discriminated against. It culminates in the need to change occupation, especially when the upper limb is affected. Therefore, the research aimed at assessing the psychological well-being, social support and coping strategies of patients with amputation.

\section{Objective of the Study}

The main objective of the study is to carry out an assessment of the psychological well-being of respondents with amputation attending clinics at the National Orthopedic Hospital, Lagos State.

The specific objectives are to:

1. Assess the psychological status of patients with amputation attending clinics at the National Orthopedic Hospital, Lagos State;

2. Identify the coping strategies employed by patients with amputation attending clinics at National Orthopaedic Hospital, Igbobi.

3. Assess the social support available to patients with amputation attending clinics at National Orthopaedic Hospital, Igbobi. 


\section{Research Questions}

1. What is the degree of psychological well-being of patients with amputation attending clinics at National Orthopaedic Hospital, Igbobi, Lagos State.

2. What are the coping strategies employed by patients with amputation attending clinics at National Orthopaedic Hospital, Igbobi, Lagos State.

3. To what extent is the social support system available to patients with amputation attending National Orthopaedic Hospital, Igbobi, Lagos State.

\section{Methodology}

The study adopts the descriptive cross-sectional method designed to investigate the psychological well-being of amputees.

\section{Setting}

The study was carried out at the National Orthopaedic Hospital, Igbobi, Lagos, which is located along the ever-busy motorway (Ikorodu Road) in Lagos State.

\section{Target Population}

The target population of this study will be amputees attending orthopedic clinics at the National Orthopedic Hospital, Lagos State.

\section{Inclusion and Exclusion criteria}

Patients that had amputation of any part of their limbs attending clinics in the hospital, those still on admission in the wards and those referred to the prosthesis unit are included in the study.

Patients with orthopaedic conditions not related to amputation of any part of the limb are excluded from the study.

\section{Sample size determination and sampling technique}

Total enumeration method was used to elicit response from patients with amputation attending clinics in the hospital; purposive sampling method was employed.

\section{Instrument for data collection}

The researcher adapted the Ryff scale of psychological well-being. Three of the domains in Ryff scale are AUTONOMY, RELATEDNESS and COMPETENCE, which are the basic psychological needs related to the psychological well-being of patients with amputation. Questionnaire is the instrument of data collection in the study; however, structured interviews were employed in line with the research questions developed.

The questionnaire consists of four sections: Section A to Section D.

Section A is socio-demographic data, with 10 open and close ended questions. 
Section B consists of 20 items for the assessment of psychological well-being of patients with amputation.

Section $\mathrm{C}$ is made up of 12 items for assessing the level of social support perceived by patients with amputation.

Section D consists of 8 items to elicit the coping strategies against psychological distress among patients with amputation.

The options provided for parts B and C are based on the 4-point Likert scale of 'A' - 'Agreed', 'SA' - 'Strongly Agreed', 'D' - 'Disagreed', 'and SD' - 'Strongly Disagreed', while part D has Not at all (NA), To an extent (TE), To a large extent (TLE), and To a very large extent (TVLE), respectively.

The data collected in the two administrations was collated, coded and analyzed using Cronbach Alpha reliability with coefficient of 0.74 deemed reliable and fit for use in the study.

Method of Data Analysis: The Statistical Package for the Social Sciences (version 23) was used in analyzing the collected data. The research questions were answered using mean (2.5) and standard deviation.

\section{DATA ANALYSIS}

\section{Social Demographic Characteristics of Respondents}

Table 4.1 showing distribution of respondents by socio-demographic characteristics, $\mathrm{N}=74$

\begin{tabular}{|c|c|c|c|c|}
\hline SN & \multicolumn{2}{|l|}{ Variable $(\mathrm{N}=74)$} & Frequency & Percent (\%) \\
\hline \multirow{7}{*}{1} & \multirow[t]{7}{*}{ Age } & Less than 20 & 7 & 9.5 \\
\hline & & $21-25$ & 6 & 8.1 \\
\hline & & $26-30$ & 8 & 10.8 \\
\hline & & $31-35$ & 15 & 20.3 \\
\hline & & $36-40$ & 8 & 10.8 \\
\hline & & 41 above & 30 & 40.5 \\
\hline & & Total & 74 & 100.0 \\
\hline \multirow[t]{3}{*}{2} & \multirow[t]{3}{*}{ Gender } & Male & 42 & 56.8 \\
\hline & & Female & 32 & 43.2 \\
\hline & & Total & 74 & 100.0 \\
\hline \multirow[t]{7}{*}{3} & \multirow[t]{7}{*}{ Level of Education } & Non-formal & 19 & 25.7 \\
\hline & & $\begin{array}{l}\text { Primary } \\
\text { Level }\end{array}$ & 10 & 13.5 \\
\hline & & SSCE & 23 & 31.1 \\
\hline & & NCE/OND Level & 6 & 8.1 \\
\hline & & First Degree & 13 & 17.6 \\
\hline & & Master & 3 & 4.1 \\
\hline & & Total & 74 & 100.0 \\
\hline
\end{tabular}


African Journal of Health, Nursing and Midwifery

ISSN: 2689-9418

Volume 4, Issue 3, 2021 (pp. 15-34)

www.abjournals.org

\begin{tabular}{|c|c|c|c|c|}
\hline \multirow[t]{6}{*}{4} & \multirow[t]{6}{*}{ Employment Status } & Civil servant & 17 & 23.0 \\
\hline & & Self employed & 21 & 31.1 \\
\hline & & Business-woman & 18 & 24.3 \\
\hline & & Unemployed & 12 & 16.2 \\
\hline & & Others & 4 & 5.2 \\
\hline & & Total & 74 & 100.0 \\
\hline \multirow[t]{5}{*}{5} & \multirow[t]{5}{*}{ Marital Status } & Single & 41 & 54.5 \\
\hline & & Married & 26 & 35.1 \\
\hline & & Separated & 5 & 6.8 \\
\hline & & Widows/Widower & 2 & 2.7 \\
\hline & & Total & 74 & 100.0 \\
\hline \multirow[t]{7}{*}{6} & \multirow[t]{7}{*}{ Income Level } & 20,000 & 6 & 8.1 \\
\hline & & $21,000-50,000$ & 16 & 21.6 \\
\hline & & $51,000-80,000$ & 11 & 14.9 \\
\hline & & $81,000-90,000$ & 22 & 29.8 \\
\hline & & $91,000-100,000$ & 16 & 21.6 \\
\hline & & 100,000 above & 3 & 4.1 \\
\hline & & Total & 74 & 100.0 \\
\hline \multirow[t]{3}{*}{7} & \multirow[t]{3}{*}{ Religion } & Christianity & 40 & 54.1 \\
\hline & & Islam & 34 & 45.9 \\
\hline & & Total & 74 & 100.0 \\
\hline \multirow[t]{3}{*}{8} & Type of Amputation & Lower limb & 57 & 77.0 \\
\hline & & Upper Limb & 17 & 23.0 \\
\hline & & Total & 74 & 100.0 \\
\hline \multirow[t]{4}{*}{9} & \multirow[t]{4}{*}{ Reason for Amputation } & Medical causes & 37 & 50.0 \\
\hline & & Trauma & 36 & 48.6 \\
\hline & & Others & 1 & 1.4 \\
\hline & & Total & 74 & 100.0 \\
\hline \multirow[t]{3}{*}{10} & Duration of Amputation & $<6$ months & 60 & 81.1 \\
\hline & & $>=6$ months & 14 & 18.9 \\
\hline & & Total & 74 & 100.0 \\
\hline
\end{tabular}

Table 4.1 indicated that respondents within the age of 41 years and above have the highest frequency of 30 (40.5\%), followed by those within the age range of 31-35 with $15(20.3 \%)$, while the least frequency emanated from the age range of less than 20 years with $7(9.5 \%)$. Similarly, males were $42(56.8 \%)$, females were $32(42.2 \%)$. For the level of education, nonformal education had 19 (25.7\%), primary school level had 10 (13.5\%), SSCE had $23(31.1 \%)$, NCE/OND level had 6 (8.1\%), First degree 13 (17.6\%) and Masters 3 (4.1\%). Employment status had the following frequencies: civil servants 17 (23\%), self-employed $21(31.1 \%)$, business women $18(24.3 \%)$, unemployed $12(16.2 \%)$, and others $4(5.2 \%)$ respectively. Marital status had the following: single 41 (54.5\%), married 26 (25.1\%), separated $5(6.8 \%)$, and widow/widower $2(2.7 \%)$. Meanwhile, the income frequencies had the following: 20,000 had 6 (8.1\%), 21,000-50,000 had 16 (21.6\%), 51,000-80,000 had 11 (14.9\%), 81,000-90,000 
had $22(29.8 \%), 91,000-100,000$ had $16(21.6 \%)$, and 100,000 and above had $3(4.1 \%)$. For the type of amputation, the lower limb had $57(77 \%)$ and the upper limb had $17(23 \%)$. Regarding reason for amputation, medical reasons had $37(50 \%)$, trauma $36(48.6 \%)$, and others $1(1.4 \%)$ respectively. For duration of amputation, less than 6 months had $60(81.1 \%)$ and more than 6 months had 14 (18.9\%).

\section{Research Questions}

1. What is the degree of psychological well-being of patients with amputation attending clinics at National Orthopaedic Hospital, Igbobi, Lagos State?

Table 4.2 showing the degree of psychological well-being of patients with amputation attending clinics at National Orthopaedic Hospital, Igbobi, Lagos State.

In view of my present status, I feel disappointed about my achievements in life.

\begin{tabular}{llll} 
Category & Criteria & Frequency $\%$ & Remarks \\
\hline
\end{tabular}

\begin{tabular}{lllll} 
SA/A & High & 42 & 56.7 & $\begin{array}{l}\text { Respondents with the highest level of } \\
\text { disappointment about life's achievement }\end{array}$ \\
\hline SD/D & Low & 32 & 43.3 & $\begin{array}{l}\text { Respondents with the lowest level of } \\
\text { disappointment about life' achievement }\end{array}$
\end{tabular}

I feel lonely often because I now have few close friends due to my present condition.

\begin{tabular}{lllll} 
Category & Criteria & Frequency & $\%$ & Remark \\
\hline SA/A & High & 42 & 56.7 & $\begin{array}{l}\text { Respondents with the highest level } \\
\text { of loneliness }\end{array}$ \\
\hline SD/D & Low & 32 & 43.3 & $\begin{array}{l}\text { Respondents with the lowest level } \\
\text { of loneliness }\end{array}$ \\
\hline
\end{tabular}

I don't feel I am in charge of my life anymore.

\begin{tabular}{lllll} 
Category & Criteria & Frequency & \% & Remark \\
\hline SA/A & Low & 28 & 37.8 & $\begin{array}{l}\text { Respondents with the lowest level } \\
\text { disappointment about life }\end{array}$ \\
\hline SD/D & High & 46 & 62.2 & $\begin{array}{l}\text { Respondents with the highest level } \\
\text { of disappointment about life }\end{array}$ \\
\hline
\end{tabular}


Nowadays, I live life one day at a time and don't really think about the future anymore.

\begin{tabular}{lllll} 
Category & Criteria & Frequency & $\%$ & Remark \\
\hline SA/A & Low & 28 & 37.8 & $\begin{array}{l}\text { Respondents with the lowest level } \\
\text { of disappointment about the future }\end{array}$ \\
\hline SD/D & High & 46 & 62.2 & $\begin{array}{l}\text { Respondents with the highest level } \\
\text { of disappointment about the future }\end{array}$ \\
\hline
\end{tabular}

My decisions are now being influenced by those around me, which I don't like.

\begin{tabular}{lllll} 
Category & Criteria & Frequency & $\%$ & Remark \\
\hline SA/A & Low & 37 & 50.0 & $\begin{array}{l}\text { Respondents with the lowest level } \\
\text { of decision influence }\end{array}$ \\
\hline SD/D & High & 37 & 50.1 & $\begin{array}{l}\text { Respondents with the highest level } \\
\text { of decision influence }\end{array}$ \\
\hline
\end{tabular}

The demands of everyday life since amputation often get me down and distressed.

\begin{tabular}{lllll}
\hline Category & Criteria & Frequency & $\%$ & Remark \\
\hline SA/A & High & 68 & 92.0 & $\begin{array}{l}\text { Respondents who are often } \\
\text { distressed about daily events at the } \\
\text { highest level }\end{array}$ \\
\hline SD/D & Low & 6 & $\begin{array}{l}\text { Respondents who are often } \\
\text { distressed about daily events at the } \\
\text { lowest level }\end{array}$ \\
\hline
\end{tabular}

Maintaining close relationships has been difficult and frustrating for me since amputation set in.

\begin{tabular}{lllll}
\hline Category & Criteria & Frequency & $\%$ & Remark \\
\hline SA/A & High & 52 & 69.9 & $\begin{array}{l}\text { Respondents with the highest level } \\
\text { of difficulty in getting close } \\
\text { relationship }\end{array}$ \\
\hline SD/D & Low & 22 & $\begin{array}{l}\text { Respondents with the lowest level } \\
\text { of difficulty in getting close } \\
\text { relationship. }\end{array}$ \\
\hline
\end{tabular}


Nowadays, I worry about what people say about me based on my condition.

\begin{tabular}{lllll}
\hline Category & Criteria & Frequency & $\%$ & Remark \\
\hline SA/A & High & 52 & 69.9 & $\begin{array}{l}\text { Respondents worried at the highest } \\
\text { level about what others say about } \\
\text { their condition }\end{array}$ \\
\hline SD/D & Low & 22 & $\begin{array}{l}\text { Respondents worried at the lowest } \\
\text { level about what others say about } \\
\text { their condition }\end{array}$ \\
\hline
\end{tabular}

In view of my present condition, it seems that I don't have a sense of direction and purpose in life anymore.

\begin{tabular}{lllllr} 
Category & Criteria & Frequency & $\%$ & Remark & \\
\hline SA/A & Low & 25 & 33.8 & $\begin{array}{l}\text { Respondents who lack } \\
\text { direction/purpose in life at the } \\
\text { lowest level }\end{array}$ \\
SD/D & High & 49 & 66.3 & $\begin{array}{l}\text { Respondents who lack } \\
\text { direction/purpose in life at the } \\
\text { highest level }\end{array}$ \\
\hline
\end{tabular}

I do not fit very well with the people and the community around me anymore due to my condition.

\begin{tabular}{lllll}
\hline Category & Criteria & Frequency & $\%$ & Remark \\
\hline SA/A & High & 49 & 66.2 & $\begin{array}{l}\text { Respondents who at the highest } \\
\text { level think they don't fit well with } \\
\text { people around them. }\end{array}$ \\
\hline SD/D & Low & 25 & $\begin{array}{l}\text { Respondents who at the lowest } \\
\text { level think they don't fit well with } \\
\text { people around them. }\end{array}$ \\
\hline
\end{tabular}

I haven't really improved much in my life goals since my present condition started.

\begin{tabular}{lllll} 
Category & Criteria & Frequency & $\%$ & Remark \\
\hline SA/A & High & 43 & 58.1 & $\begin{array}{l}\text { Respondents with the highest level } \\
\text { of thought on stagnancy since } \\
\text { amputation }\end{array}$ \\
\hline SD/D & Low & 31 & 41.9 & $\begin{array}{l}\text { Respondents with the lowest level } \\
\text { of thought on stagnancy since } \\
\text { amputation }\end{array}$ \\
\hline
\end{tabular}


Recently, all my daily activities seem unimportant to me.

\begin{tabular}{lllll}
\hline Category & Criteria & Frequency & $\%$ & Remark \\
\hline SA/A & Low & 37 & 50 & $\begin{array}{l}\text { Respondents who at the lowest } \\
\text { level feel discouraged about daily } \\
\text { activities }\end{array}$ \\
\hline SD/D & High & 37 & $\begin{array}{l}\text { Respondents who at the highest } \\
\text { level feel discouraged about daily } \\
\text { activities }\end{array}$ \\
\hline
\end{tabular}

As a result of my present condition, I have difficulty arranging my life in a way that is satisfying to me.

\begin{tabular}{lllll} 
Category & Criteria & Frequency & $\%$ & Remark \\
\hline SA/A & High & 61 & 82.5 & $\begin{array}{l}\text { Respondents with the highest level } \\
\text { of lack of life satisfaction }\end{array}$ \\
\hline SD/D & Low & 37 & 17.6 & $\begin{array}{l}\text { Respondents with the lowest level } \\
\text { of lack of life satisfaction }\end{array}$ \\
\hline
\end{tabular}

I feel that my personality status has been significantly lowered since this condition set in.

\begin{tabular}{lllll}
\hline Category & Criteria & Frequency & $\%$ & Remark \\
\hline SA/A & High & 68 & 92 & $\begin{array}{l}\text { Respondents with the highest level } \\
\text { of lack of personality status. }\end{array}$ \\
\hline SD/D & Low & 6 & 8.0 & $\begin{array}{l}\text { Respondents with the lowest level } \\
\text { of lack of personality status. }\end{array}$ \\
\hline
\end{tabular}

I have not been able to enjoy the trusting relationships I enjoyed before amputation set in

\begin{tabular}{lllll} 
Category & Criteria & Frequency & $\%$ & Remark \\
\hline SA/A & High & 60 & 81.1 & $\begin{array}{l}\text { Respondents with the highest level } \\
\text { of lack of trusting relationships } \\
\text { since amputation }\end{array}$ \\
\hline SD/D & Low & 14 & $\begin{array}{l}\text { Respondents with the lowest level } \\
\text { of lack of trusting relationships } \\
\text { since amputation }\end{array}$ \\
\hline
\end{tabular}


Presently, I feel overwhelmed by what amputation is making me go through.

\begin{tabular}{lllllr} 
Category & Criteria & Frequency & $\%$ & Remark & \\
\hline SA/A & High & 66 & 89.2 & $\begin{array}{l}\text { Respondents who feel } \\
\text { overwhelmed about amputation at } \\
\text { the highest level }\end{array}$ \\
\hline SD/D & & \multicolumn{3}{l}{$\begin{array}{l}\text { Respondents who feel } \\
\text { overwhelmed about amputation at } \\
\text { the lowest level }\end{array}$} \\
\hline
\end{tabular}

Presently, I judge myself based on what others say about me, not what I feel or think about myself.

\begin{tabular}{lllll} 
Category & Criteria & Frequency & $\%$ & Remark \\
\hline SA/A & High & 64 & 86.5 & $\begin{array}{l}\text { Respondents with the highest level } \\
\text { of self judgment on what people } \\
\text { say }\end{array}$ \\
\hline SD/D & Low & 10 & $\begin{array}{l}\text { Respondents with the lowest level } \\
\text { of self judgment on what people } \\
\text { say }\end{array}$ \\
\hline
\end{tabular}

I have given up on trying to improve my life since amputation won't allow me to bring positive changes to my life.

\begin{tabular}{lllll}
\hline Category & Criteria & Frequency & $\%$ & Remark \\
\hline SA/A & Low & 24 & 32.4 & $\begin{array}{l}\text { Respondents that have given up } \\
\text { about life at the highest level }\end{array}$ \\
\hline SD/D & High & 50 & 67.7 & $\begin{array}{l}\text { Respondents that have given up } \\
\text { about life at the lowest level }\end{array}$ \\
\hline
\end{tabular}

I have given up hope of taking positive steps in life since I am not a complete human anymore due to amputation.

\begin{tabular}{lllll} 
Category & Criteria & Frequency & $\%$ & Remark \\
\hline & & & $\begin{array}{l}\text { Respondents who have given up } \\
\text { hope at the lowest level of taking } \\
\text { positive steps in life since } \\
\text { amputation }\end{array}$ \\
SA/A & Low & 25 & 33.8 & $\begin{array}{l}\text { Respondents who have given up } \\
\text { hope at the highest level of taking } \\
\text { positive steps in life since } \\
\text { amputation }\end{array}$ \\
\hline SD/D & & &
\end{tabular}


Research Question 2: What are the coping strategies employed by patients with amputation attending clinics at National Orthopaedic Hospital, Igbobi, Lagos State?

Table 4.3 showing the frequencies of the coping strategies employed by patients with amputation attending clinics at National Orthopaedic Hospital, Igbobi, Lagos State.

Not at all (NA), To a very small extent (TVS), To an extent (TAE), To a large extent (TLE), and To a very large extent (TVLE) respectively.

\begin{tabular}{|c|c|c|c|c|}
\hline & Variable $(\mathrm{N}=74)$ & & Frequency & Percent (\%) \\
\hline \multirow[t]{6}{*}{1} & \multirow{6}{*}{$\begin{array}{l}\text { In order to avoid and also cope with } \\
\text { psychological distress, I distance myself } \\
\text { from people. }\end{array}$} & NA & 30 & 40.5 \\
\hline & & TVS & 14 & 18.9 \\
\hline & & TAE & 21 & 28.4 \\
\hline & & TLE & 6 & 8.1 \\
\hline & & TVLE & 3 & 4.1 \\
\hline & & Total & 74 & 100.0 \\
\hline \multirow[t]{6}{*}{2} & \multirow{6}{*}{$\begin{array}{l}\text { In order to avoid and also cope with } \\
\text { psychological distress, I use the social } \\
\text { support of those around me. }\end{array}$} & NA & 4 & 5.4 \\
\hline & & TVS & 22 & 29.7 \\
\hline & & TAE & 16 & 21.6 \\
\hline & & TLE & 16 & 21.6 \\
\hline & & TVLE & 16 & 21.6 \\
\hline & & Total & 74 & 100 \\
\hline \multirow[t]{6}{*}{3} & \multirow{6}{*}{$\begin{array}{l}\text { I believe in prayers, moving closer to } \\
\text { God and engaging in other religious } \\
\text { activities as the only means of coping } \\
\text { with my situation. }\end{array}$} & NA & 1 & 1.4 \\
\hline & & TVS & 6 & 8.1 \\
\hline & & TAE & 17 & 23.0 \\
\hline & & TLE & 23 & 31.1 \\
\hline & & TVLE & 27 & 36.5 \\
\hline & & Total & 74 & 100 \\
\hline \multirow[t]{6}{*}{4} & \multirow{6}{*}{$\begin{array}{l}\text { I consume lots of alcoholic drinks in } \\
\text { order to cope with my situation and } \\
\text { psychological distress. }\end{array}$} & $\mathrm{NA}$ & 29 & 39.2 \\
\hline & & TVS & 31 & 41.9 \\
\hline & & TAE & 4 & 5.4 \\
\hline & & TLE & 6 & 8.1 \\
\hline & & TVLE & 4 & 5.4 \\
\hline & & Total & 74 & 100 \\
\hline \multirow[t]{6}{*}{5} & \multirow{6}{*}{$\begin{array}{l}\text { I use excessive drugs to cope with } \\
\text { psychological distress. }\end{array}$} & NA & 59 & 79.7 \\
\hline & & TVS & 9 & 12.2 \\
\hline & & TAE & 0 & 0 \\
\hline & & TLE & 6 & 8.1 \\
\hline & & TVLE & 0 & 0 \\
\hline & & Total & 74 & 100 \\
\hline
\end{tabular}




\begin{tabular}{|l|l|l|l|l|}
\hline 6. & \multirow{2}{*}{$\begin{array}{l}\text { I browse the internet excessively to } \\
\text { engage my mind so as to forget my }\end{array}$} & NA & 13 & 17.6 \\
\cline { 3 - 5 } distress. & TVS & 19 & 25.7 \\
\cline { 3 - 4 } & & TAE & 18 & 24.3 \\
\cline { 3 - 4 } & & TLE & 18 & 24.3 \\
\cline { 3 - 4 } & TVLE & 6 & 8.1 \\
\cline { 3 - 4 } & Total & $\mathbf{7 4}$ & $\mathbf{1 0 0}$ \\
\hline \multirow{2}{*}{7} & \multirow{2}{*}{$\begin{array}{l}\text { I watch TV alone a lot to cope with } \\
\text { psychological distress. }\end{array}$} & NA & 4 & 5.4 \\
\cline { 3 - 4 } & & TVS & 6 & 8.1 \\
\cline { 3 - 4 } & TAE & 0 & 0 \\
\cline { 3 - 4 } & TLE & 22 & 29.7 \\
\cline { 3 - 4 } & TVLE & 20 & 27.0 \\
\cline { 3 - 4 } & Total & $\mathbf{7 4}$ & $\mathbf{1 0 0}$ \\
\hline
\end{tabular}

Research Question 3. To what extent is the social support system available to patients with amputation attending National Orthopaedic Hospital, Igbobi, Lagos State?

Table 4.4 showing the frequencies of the extent of the social support system available to patients with amputation attending National Orthopaedic Hospital, Igbobi, Lagos State.

\begin{tabular}{|c|c|c|c|c|}
\hline Variables & Yes & & No & \\
\hline & Freq & $\%$ & Freq & $\%$ \\
\hline $\begin{array}{l}\text { My family members try their best every day to give me the best } \\
\text { support. }\end{array}$ & 70 & 94.7 & 4 & 5.4 \\
\hline $\begin{array}{l}\text { My friends always visit me and show that they care through their } \\
\text { financial support. }\end{array}$ & 57 & 77.1 & 17 & 23.0 \\
\hline $\begin{array}{l}\text { There is a special person who is around whenever I need } \\
\text { assistance for anything. }\end{array}$ & 56 & 75.7 & 18 & 24.3 \\
\hline $\begin{array}{l}\text { My family members ensure that I get emotional help and support } \\
\text { whenever they see the need. }\end{array}$ & 62 & 83.8 & 12 & 16.2 \\
\hline $\begin{array}{l}\text { I always get support whenever I need it to share moments of joy } \\
\text { and sorrow. }\end{array}$ & 55 & 74.3 & 19 & 25.7 \\
\hline $\begin{array}{l}\text { I talk about my problems with my family freely and I get support } \\
\text { where needed. }\end{array}$ & 62 & 83.8 & 12 & 16.2 \\
\hline $\begin{array}{l}\text { My friends, especially the closest ones, always try to be of } \\
\text { assistance to me whenever I need them. }\end{array}$ & 55 & 74.3 & 19 & 25.7 \\
\hline $\begin{array}{l}\text { I also have friends with whom I can share my moments of joy } \\
\text { and sorrow. }\end{array}$ & 48 & 64.9 & 26 & 35.2 \\
\hline $\begin{array}{l}\text { I can always count on my family and friends for support } \\
\text { whenever I need them. }\end{array}$ & 59 & 79.8 & 15 & 20.3 \\
\hline $\begin{array}{l}\text { I talk about my challenges with some friends and I get support } \\
\text { where needed. }\end{array}$ & 54 & 73 & 20 & 27.3 \\
\hline $\begin{array}{l}\text { I sometimes get the needed social support even from my } \\
\text { neighbours in my immediate environment and in my general } \\
\text { neighbourhood. }\end{array}$ & 57 & 77.1 & 17 & 23 \\
\hline $\begin{array}{l}\text { My family is always willing to assist me in taking relevant } \\
\text { decisions whenever I need to make them, based on my present } \\
\text { situation. }\end{array}$ & 57 & 77.1 & 17 & 23 \\
\hline
\end{tabular}




\section{DISCUSSION OF FINDINGS}

\section{Social Demographic Characteristics of Respondents}

Table 4.1 indicated that respondents within the age of 41 years and above have the highest frequency of $30(40.5 \%)$, followed by those within the age range of 31-35 with $15(20.3 \%)$, while the least frequency emanated from the age range of less than 20 years with $7(9.5 \%)$. Similarly, males were 42 (56.8\%), females were 32 (42.2\%). For level of education, non-formal education had 19 (25.7\%), primary school level had 10 (13.5\%), SSCE had $23(31.1 \%)$, NCE/OND level had 6 (8.1\%), First degree 13 (17.6\%) and Masters 3 (4.1\%). Employment status gave the following frequencies: civil servant 17 (23\%), self-employed 21 (31.1\%), business women 18 (24.3\%), unemployed $12(16.2 \%)$, and others $4(5.2 \%)$ respectively. Marital status had the following: single 41 (54.5\%), married 26 (25.1\%), separated $5(6.8 \%)$, and widows/widower $2(2.7 \%)$. Meanwhile, the income frequencies had the following: 20,000 had $6(8.1 \%), 21,000-50,000$ had 16 (21.6\%), 51,000-80,000 had 11 (14.9\%), 81,000-90,000 had $22(29.8 \%), 91,000-100,000$ had $16(21.6 \%)$, and 100,000 and above had $3(4.1 \%)$. For the type of amputation, the lower limb had 57 (77\%) and the upper limb had 17 (23\%). Regarding for amputation, medical reasons had 37 (50\%), trauma $36(48.6 \%)$, and others $1(1.4 \%)$ respectively. For duration of amputation, less than 6 months had $60(81.1 \%)$ and more than 6 months had $14(18.9 \%)$. The above social demographic characteristics are associated with the frequency of Steger, Kashdan and Oishi (2008).

Research Questions 1. What is the degree of psychological well-being of patients with amputation attending clinics at National Orthopaedic Hospital, Igbobi, Lagos State?

The characterization shows that the majority of the respondents are of high level of disappointment, discouragement, dissatisfaction and despondency about their present conditions and lives. The following support this view:

In view of my present status, I feel disappointed about my achievements in life (high-57\%). I feel lonely often because I now have few close friends due to my present condition (high-57\%). The demands of everyday life since amputation often get me down and distressed (high-92\%). Maintaining close relationships has been difficult and frustrating for me since amputation set in (high-70\%). Nowadays, I worry about what people say about me based on my condition (high-70\%). I do not fit very well with the people and the community around me anymore due to my condition (high-66.2\%). I haven't really improved much in my life goals since my present condition started (high-58\%). As a result of my present condition, I have difficulty arranging my life in a way that is satisfying to me (high-82\%). I feel that my personality status has been significantly lowered since this condition set in (high-92\%). I have not been able to enjoy the trusting relationships I enjoyed before amputation set in (high-81\%). Presently, I feel overwhelmed by what amputation is making me go through (high-89\%). Presently, I judge myself based on what others say about me, not what I feel or think about myself (high-87\%).

Only a few respondents think otherwise with 'strongly disagree' and 'disagree'. The following views supported this notion:

I don't feel I am in charge of my life anymore (high-62\%). Nowadays, I live life one day at a time and don't really think about the future anymore (high-62\%). My decisions are now being influenced by those around me, which I don't like (high-50.1\%). In view of my present condition, it seems that I don't have a sense of direction and purpose in life anymore (high- 
$66 \%$ ). Recently, all my daily activities seem unimportant to me (high-50.1). I have given up on trying to improve my life since amputation won't allow me to bring positive changes to my life (high-68\%). I have given up hope of taking positive steps in life since I am not a complete human anymore due to amputation (high-66\%).

These discussions are in line with the research that shows that amputation is a process that psychologically stresses patients and their caregivers. According to researchers like Ide (2011), amputees evidently experience depressive disorders, with feelings of sadness, discouragement, apathy, guilt and disappointment with self. Psychological distress involves the amassing of multiple intense negative emotions of which anxiety and depression, among other negative emotions, are factors.

Research Question 2: What are the coping strategies employed by patients with amputation attending clinics at National Orthopaedic Hospital, Igbobi, Lagos State?

The discussions on the frequencies of the coping strategies employed by patients with amputation attending clinics at National Orthopaedic Hospital, Igbobi, Lagos State revealed that most of the respondents were positive about their coping strategies while only a few of them had negative ideas about the coping strategies as outlined below:

Not at all (NA), To a very small extent (TVS), To an extent (TAE), To a large extent (TLE), and To a very large extent (TVLE) respectively.

Question 1. In order to avoid and also cope with psychological distress, I distance myself from people (Not at all-41\%).

Question 2. In order to avoid and also cope with psychological distress, I use the social support of those around me (To a very small extent-30\%).

Question 3. I believe in prayers, moving closer to God and engaging in other religious activities as the only means of coping with my situation (To a very large extent-37\%).

Question 4. I consume lots of alcoholic drinks in order to cope with my situation and psychological distress (To a very small extent-42\%) .

Question 5. I use excessive drugs to cope with psychological distress (To a very small extent$26 \%)$.

Question 6. I browse the internet excessively to engage my mind so as to forget my psychological distress $(26 \%)$.

Question 7. I watch TV alone a lot to cope with psychological distress (To a large extent-30\%).

These illustrations go in line with the research carried out by Livneh et al. (1999), which found that greater active problem solving was negatively associated with depression and internalized anger and positively associated with adjustment and acceptance of disability. In contrast, emotion focused coping and cognitive disengagements were positively associated with depression, externalized hostility and lack of acceptance of disability. 
Research Question 3. To what extent is the social support system available to patients with amputation attending National Orthopaedic Hospital, Igbobi, Lagos State?

As illustrated in Table 4.4, all the respondents were positive in their responses to the social support available to them with respect to their health status. All the questions asked had high percentages of responses. Such questions include:

My family members try their best every day to give me the best support (Yes-95\%). My friends always visit me and show that they care through their financial supports (yes-77\%). There is a special person who is around whenever I need assistance for anything (yes-76\%). My family members ensure that I get emotional help and support whenever they see the need (yes-84\%). I always get support whenever I need it to share moment of joy and sorrow (yes-74\%). I talk about my problems with my family freely and I get support where needed (yes-84). My friends, especially the closest ones, always try to be of assistance to me whenever I need them (yes$74 \%$ ). I also have friends with whom I can share my moments of joy and sorrow (yes-85\%). I can always count on my family and friends for support whenever I need them (yes-80). I talk about my challenges with some friends and I get support where needed (yes-73\%). I sometimes get the needed social support even from my neighbours in my immediate environment and in my general neighbourhood (yes-77\%). My family is always willing to assist me in taking relevant decisions whenever I need to make one, based on my present situation (yes-77\%). I talk about my challenges with some friends and I get supports where needed (yes-85\%).

These decisions were supported by the research carried out Singh, Hunter and Philip (2007) primarily sought to examine the relative progression of depressive and anxiety symptoms shortly after amputation, and again after a period of inpatient rehabilitation. The researchers investigated this phenomenon by using a unit of 105 amputees at a rehabilitation ward. These amputees were initially screened for the presence of symptoms of anxiety and depression. It was realized that at admission, 28 amputees representing $26.7 \%$ of the participants had symptoms of depression and 26 amputees representing $24.8 \%$ patients had symptoms of anxiety. The number of patients who had depression and anxiety at the time of discharge dropped to 4 patients, representing $3.8 \%$ of participants and 5 patients, representing $4.8 \%$ of the participants. After a couple of days, the level of depression and anxiety among the patients dropped to a mean of 54.3. These progressive reductions were statistically significant, as was the association between patients having symptoms of both depression and anxiety.

\section{RECOMMENDATIONS}

In order to address and explore the concerns we have highlighted in the extant literature on adjustment to amputation, more longitudinal research is needed to examine adjustment amongst people immediately post amputation and throughout the first few years following their limb loss and rehabilitation. Due to the large number of factors that have been found to influence the process of adjustment, and the importance of understanding the meaning of these for the individuals concerned, we recommend that both qualitative and quantitative research designs be used in examining the nature of their interrelationships.

The results of this study reflect the inherent complexity of psychological well-being, social and coping strategies in the lives of human beings and their interrelationships. Future research should be conducted on a larger sample, using a mixed-method approach to uncover a large 
diversity of coping efforts used by individuals who had a lower limb amputation. It is important to develop knowledge not just about which strategies are used but also how they are used, and if they promote positive adjustment and in which context. This type of information is crucial to support the efforts of people with amputation and to support the work of health care professionals.

\section{REFERENCES}

Abbas, Z. G., \& Archibald, L. K. (2005). Epidemiology of the diabetic foot in Africa. Med Sci Monit, 11(2): 62-270.

Abeyasinghe, N. L., de Zoysa, P., Bandara, K.M., Bartholameuz, N.A., Bandara, J.M. (2012). The prevalence of symptoms of post-traumatic stress disorder among soldiers with amputation of a limb or spinal injury: A report from a rehabilitation centre in Sri Lanka. Psychology Health Med,17: 376-81.

Abdallah, S., Michaelson, J., \& Stoll, L. (2013). Quality of life in Europe: Subjective wellbeing. Brussels: Eurofound.

Adebayo, O. A. \& Ayiade, A. (2011). Psychological wellbeing of lower-limo amputees in two Nigerian teaching hospitals: the role of psychological and demographic factors. Nigerian Journal of Applied Psychology, 12(2): 49

Adejurno, A.O. (2011). Psycho-demographic factors as determinant" of perceived' accident vulnerability among commercial I motorcyclists in two Nigerian cities. Ibadan Journal of the Social Sciences, 8 (2), (in press).

Adejurno, A.O., \& Adcjurno, P. O. (2005). Time to act against medical I collusion in punitive amputations. British Medical Journal, 330 1277-1289

Ahmed, S. (2010). The promise of Happiness. London: Duke University Press.

Ajibade, A., Akinniyi, O. T., \& Okoye, C. S. (2013). Indications and Complications of Major Limb Amputations in Kano, Nigeria. Ghana Med Journal, 47(4),185-8.

Barnes, M., Taylor, D., \& Ward, E. (2013). Being well enough in old age. Critical Social Policy, 33 (3).

Behel, J. M., Rybarczyk, B., Elliott, T. R., Nicholas, N. J., \& Nyenhuis, D. (2002). The role of perceived vulnerability in adjustment to lower extremity amputation: A preliminary investigation. Rehabilitation Psychology, 47: 92 - 105.

Belon, H.P, \& Vigoda, D. F. (2014) Emotional adaptation to limb loss. Physical Medicine and Rehabilitation Clinics of North America. 25(1), 53-74.

Bergo, M. F. C. \& Prebianchi, H. B. (2018). Emotional aspects present in the lives of amputees: a literature review. Revista Psicologia: Teoria e Prática, 20(1): 47-60.

Bhuvaneswar, C.G., Epstein, L.A., \& Stern, T.A. (2007). Reactions to amputation: recognition and treatment. The Primary Care Companion to the Journal of Clinical Psychiatry, 9(4), 303- 308.

Borsook, D. \& Becerra, L. (2009). Emotional pain without sensory pain-dream on? Neuron Preview, 61(9), 153-155.

Bryant G (2001) Stump care. American Journal of Nursing. 101 (2), 67-71.

Kılıç, B., Yücel, A. S.,, Yaman, C.,, Hergüner, G., \& Korkmaz, M. (2014). Methods of determining the amputation level of lower extremity. European Journal of Experimental Biology, 4(3):55-60

Cancer Statistics Registrations (2005). Registrations of cancer diagnosed in 2002, England. Series MB1 no. 33. London: Office of National Statistics. 
Cansever, A. (2003). Depression in men with traumatic lower part amputation: A comparison to men with surgical lower part amputation. Military Medicine, 168(2): 106-110.

Cavanagh, S.R., Shin, L.M., Karamouz, N., Rauch, S.L. (2006). Psychiatric and emotional sequelae of surgical amputation. Psychosomatics. 47(6): 459-464.

Chahine, L., \& Kanazi, G. (2007). Phantom limb syndrome: a review. Middle East Journal of Anaesthesiology. 19(2), 345-355.

Chalya, P.L., Mabula, J.B., \& Dass, R.M. (2012). Major Limb Amputations: A Tertiary Hospital Experience in Northwestern Tanzania. J Orthop Surg Res, 7:18.

Chavez, A., Milburn, K., Parry, O., \& Platt, S. (2005). Understanding and researching wellbeing: Its usage in different disciplines and potential for health research and health promotion. Health Education Journal, 64 (1): 70-87.

Chirkov, V. I., Ryan, R. M., Kim, Y., \& Kaplan, U. (2003). Differentiating autonomy from individualism and independence: A self-determination theory perspective on internalization of cultural orientations and well-being. Journal of Personality and Social Psychology, 84, 97-110.

Ryff, C.D., \& Singer, B.H. (2008). Know thyself and become what you are: A eudaimonic approach to psychological well-being. Journal of Happiness Studies, 9(1), 13-39.

Ryff, C.D. (1989a). Beyond Ponce de Leon and life satisfaction: New directions in quest of successful aging. International Journal of Behavioural Development, 12(1), 35-55.

Ryff, C.D. (2013a). Eudaimonic well-being and health: Mapping consequences of selfrealization. In A.S. Waterman (Ed.), The best within us: Positive psychology perspectives on eudaimonia, (pp. 77-98). Washington, DC: American Psychological Association.

Scottish Intercollegiate Guidelines Network (2013). Management of Chronic Pain: A National Clinical Guideline. No. 136. SIGN, Edinburgh.

Shirley, P. H. (2002). Rehabilitation nursing, process application \& outcome. (3rd ed., pp 452,476-480) Harcourt: Health sciences, Mosby.

Shukla, G.D., Sahu, S.C., Tripathi, R.P., \& Gupta, D.K. (1982). A psychiatric study of amputees. British Journal of Psychiatry, 141, 50 - 53.

Simoneau, H., \& Bergeron, J. (2003). Factors affecting motivation during the first six weeks of treatment. Addictive Behaviors, 28, 1219-1241.

Singh, R., Hunter, J. \& Philip, A. (2007). The rapid resolution of depression and anxiety symptoms after lower limb amputation. Clinical Rehabilitation, 21, 754-759.

Smith, D.G. \& Skinner, H.B. (2015). Amputations. Current Diagnosis and Treatment in Orthopedics. 5th ed. 11. Skinner HB, McMahon PJ, editors. New York: The McGrawHill Companies.

Smurr, L.M., Gulick, K., Yancosek, K., \& Ganz, O. (2008). Managing the upper extremity amputee: a protocol for success. Journal of Hand Therapy. 21(2), 160-175

Solgajová, A., Sollár, T., \& Vörösová, G. (2015). Gender, age and proactive coping as predictors of coping in patients with limb amputation. Kontakt, 17, 67-72.

Steger, M.F., Kashdan, T.B., \& Oishi, S. (2008). Being good by doing good: Daily eudaimonic activity and well-being. Journal of Research in Personality, 42, 22-42.

Tintle, S.M., Keeling, J.J., Shawen, S.B., Forsberg, J.A., \& Potter, B.K. (2010). Traumatic and trauma-related amputations: Part I: General principles and lower-extremity amputations. J Bone Joint Surg Am, 92, 2852-68.

Troister, T. \& Holden, R. R. (2010). Comparing psychache, depression and hopelessness in their associations with suicidality: a test of Sheidman's theory of suicide. Personality and Individual Differences, 49, 689-683. 
Uustal, H. (2015). Lower limb amputation, rehabilitation, and prosthetic restoration. Current Diagnosis and Treatment: Physical Medicine and Rehabilitation. Maitin IB, Cruz E, editors. New York: McGraw-Hill Education.

U.S. Department of Health and Human Services. (2000). Healthy people 2010. Washington D.C.: U.S. Government Printing Office.

Vansteenkiste, M., Lens, W., \& Deci, E. L. (2006). Intrinsic versus ex.

Viswanathan, V., \& Kumpatla, S. (2011). Pattern and Causes of Amputation in Diabetic Patients A Multicentric Study from India. Indian Diabetic Amputation Study Group, Diabetes Research Centre and M.V Hospital for Diabetes, No.4, Main Road, Royapuram, Chennai - 13, India. (A WHO collaborating Centre for Research, Education and Training in Diabetes).

Vadivelu, N., Mitra, S, \& Narayan, D. (2010). Recent advances in postoperative pain management. Yale Journal of Biology and Medicine. 83(1): 11-25.

Vázquez, C., \& Hervás, G. (Eds.), (2008). Psicología Positiva aplicada. Bilbao: Desclée de Brower.

Vázquez, C., \& Hervás, G. (Eds.) (2009). La ciencia del bienestar: Fundamentos de una Psicología Positiva. Madrid: Alianza Editorial.

Vivek, H., Kumar, K.M., \& Vikranth, S.N. (2016). Major Lower Limb Amputation: A Tertiary Hospital Experience. International Journal of Current Research, 8(8), 361624.

Waterman, A. S. (1993). Two conceptions of happiness: Contrasts of personal expressiveness (eudaimonia) and hedonic enjoyment. Journal of Personality and Social Psychology, 64, 678-691.

Weeks, S.R., Anderson-Barnes, V.C., \& Tsao, J.W. (2010). Phantom limb pain: theories and therapies. The Neurologist. 16(5): 277-286.

Williams, G. C., Cox, E. M., Hedberg, V. A., \& Deci, E. L. (2000). Extrinsic life goals and health-risk behaviors in adolescents. Journal of Applied Social Psychology, 30, 17561771.

Williamson, G.M., Schulz, R., Bridges, M.W., \& Behan, A.M. (19940. Social and psychological factors in adjustment to limb amputation. Journal of Social Behavior and Personality, 9: 249 - 268.

Winefield, H., Gill, T., Taylor, A., \& Pilkington, R.(2012). Psychological Well-Being and Psychological distress: is it necessary to measure both? Psychology of Well-Being: Theory, Research and Practice, 2 (3).

World Health Organisation (2005). World Health Organisation, \& International Society for Prosthetics and Orthotics (2005) Guidelines for training personnel in developing countries for prosthetics and orthotics services. WHO Library Cataloguing-inPublication Data.

Yusof, N.M., Rahman, J.A., \& Zulkifly, A.H., (2015). Predictors of Major Lower Limb Amputation among Type II Diabetic Patients. 